\section{Stakeholder Prioritization in Brazilian Companies Disclosing GRI Reports}

\author{
Keysa Manuela Cunha de Mascena ${ }^{\dagger}$ \\ Faculdade de Economia, Administração e Contabilidade da Universidade de São Paulo \\ Adalberto Americo Fischmann $\Omega$ \\ Faculdade de Economia, Administração e Contabilidade da Universidade de São Paulo \\ João Maurício Gama Boaventura $¥$ \\ Faculdade de Economia, Administração e Contabilidade da Universidade de São Paulo
}

\section{ABSTRACT}

This study aimed to describe the stakeholder prioritization in Brazilian companies and their relationship with the industry. In this research, prioritization is operationally defined as the preferential treatment to the interests of one stakeholder over another. The sample is composed of 90 companies with sustainability reporting adopting the Global Reporting Initiative (GRI) framework. We used the Mann-Whitney test to compare the level of treatment with the interests of internal and external stakeholders. We confirmed the hypotheses that the internal stakeholder has a higher level of treatment and that the level of treatment is influenced by characteristics of the industries. This study presents as theoretical contribution the analysis of the industry factor in stakeholders prioritization. Understanding the mechanisms of stakeholders prioritization is important for the manager to encourage relevant stakeholders to the achievement of the company's goals in its sector.

Keywords: Prioritization; Stakeholders; GRI reports; Disclosure.

\section{INTRODUCTION}

In recent decades, corporations have come to deal with a number of changes that have driven the development of different approaches in management, such as corporate social responsibility, sustainability, corporate ethics, corporate governance and environmental management. These approaches are related to the stakeholder theory, which is based on the work by Freeman (1984), Strategic Management: a stakeholder approach. The stakeholder theory presents concepts and models that consider the interests and demands of the various stakeholders of the organization in the formulation and strategic implementation.

Although the stakeholder theory has aroused interest in both the academic and managerial spheres, nonconsensual points in theory still remain, which lack theoretical evolution and empirical application. In this sense, Phillips (2003, p.160) states that an issue that historically haunts the stakeholder theory refers to how managers allocate time, attention, capacity and other scarce resources among stakeholders, that is, the issue of stakeholder prioritization.

Stakeholder prioritization is discussed in the literature from two different perspectives. The first is related to the manager's perception of
Corresponding author:

${ }^{\dagger}$ Faculdade de Economia,

Administração e Contabilidade da

Universidade de São Paulo

E-mail: keysamascena@usp.br

${ }^{\Omega}$ Faculdade de Economia,

Administração e Contabilidade da

Universidade de São Paulo

E-mail: aafischm@usp.br

${ }^{¥}$ Faculdade de Economia,

Administração e Contabilidade da

Universidade de São Paulo

E-mail: jboaventura@usp.br

Received: $11 / 20 / 2015$.

Revised: 05/02/2016.

Accepted: 06/29/2016.

Published Online: 11/01/2017. 
the importance of stakeholder, and the second is associated to the level of fulfillment of stakeholders interests.

In the first perspective, the prioritized stakeholders are those perceived by managers as more important. The stakeholder salience model proposed by Mitchell, Agle and Wood (1997) is the most adopted in this approach. The salience model suggests that stakeholders can be classified from the presence or absence of three attributes: power, legitimacy and urgency, and the greater the number of attributes, the greater the degree of stakeholder prioritization. Many empirical studies have applied this model, such as Agle, Mitchell and Sonnenfeld (1999), Parent and Deephouse (2007), Boesso and Kumar (2009) and Weber and Marley (2010).

In the second perspective, the prioritized stakeholders are those who receive the highest level of treatment of their interests. There are some studies that contribute with empirical evidence of the level of meeting stakeholders' interest, like those by Boaventura et al. (2009), Vazquez-Brust et al. (2010), Boaventura (2012) and Michelon, Boesso and Kumar (2013).

Boaventura et al. (2009) analyzed whether stakeholders interests fulfillment was subordinated to shareholders interests fulfillment, and found in their results a non-subordination, since they verified that even if the shareholders did not have their interests met, the other stakeholders interest were met. Vazquez-Brust et al. (2010) found differences between the perception of the importance of the stakeholder and the way they are treated by management, i.e., that meeting stakeholder's interest may not be related to their salience. Boaventura (2012) analyzed the dominance of stakeholders, defining it as the ability of a particular stakeholder to obtain resources from a company to meet their demands in a preferential way relative to other stakeholders. The author did not find a relationship between stakeholder dominance and its contribution to social performance and did not obtain conclusive results for the association between dominance and stakeholder power. Michelon, Boesso and Kumar (2013) tested the relationship between resource allocation in seven areas of social responsibility and financial performance, finding that the allocation of resources to priority stakeholders is positively related to the company's financial performance, although the relationship does not occur in all the seven surveyed areas.

Previous studies have tested relationships between the stakeholder prioritization and different variables, such as social and financial performance, power, stakeholder salience and shareholder primacy. The variables contemplated in previous studies are related to managers' perceptions or to corporate performance. However, others factors could determining the level of stakeholder treatment that are not related to management, but to other characteristics of the company, such as its sector of activity. In this way, it becomes relevant to investigate how the industry factor can be related to stakeholder prioritization.

The objective of this research is to analyze stakeholder prioritization in Brazilian companies and their relationship with the industry (economic sector). Stakeholder prioritization is operationally defined in this research as the preferential treatment of the interests of one stakeholder over another.

To achieve the main objective of the research, the following specific objectives were established: (a) To identify the stakeholder prioritization of the companies; (b) Analyze the relationship between the stakeholder prioritization and the industry variable.

Empirical analysis will be conducted in annual reports of for-profit companies that adopt the structure of the Global Reporting Initiative (GRI) in Brazil. In this way, this research presents a method of measuring the fulfillment stakeholders interests from the disclosure of the stakeholders interest being met reported in the GRI reports.

The theoretical contribution of this research is in the analysis of the industry factor in stakeholder prioritization, considered by the level that their interests are met. Considering that the industry variable is important in performance and strategy studies, this study 
BBR

15,1

19

contributes to the analysis of its influence on stakeholder prioritization. This research also seeks to offer an empirical contribution on the phenomenon of stakeholder prioritization in the Brazilian context.

This study presents a managerial contribution since meeting the interests of the stakeholders affects the engagement of the stakeholder in the organization, being a positive reinforcement for those who cooperate more with the company. Understanding the mechanisms of the stakeholder prioritization is important for the manager to encourage stakeholders with greater strategic importance to carry out the activities of the company in their sector of activity. In addition, management undertakes a great deal of effort to measure socioenvironmental performance and to disclose it in reports, which are also tools for engaging stakeholders. This effort can be used by the company in the management of the performance in its relationship with the stakeholders.

\section{THEORETICAL FRAMEWORK}

\subsection{STAKEHOLDER PRIORITIZATION}

In the stakeholder view, the objective function of the firm is to serve as a vehicle for coordination of stakeholder interests (BOAVENTURA et al., 2009). This objective function proposed in stakeholder theory is criticized by many authors, especially in defense of the theory of the firm. Phillips, Freeman and Wicks (2003) and Phillips (2003) defend the stakeholder theory from criticisms that suggest that the theory would not offer a clear criteria for prioritization in decision making. Phillips (2003) argues that prioritization can be interpreted in different ways, but the stakeholder theory indicates ways in which managers can determine how to prioritize the interests of some stakeholders. For example, the criterion of meritocracy, that is, meeting the stakeholders according to their relative contribution to the company (PHILLIPS, 2003; PHILLIPS; FREEMAN; WICKS, 2003).

We observe in the literature that the stakeholder prioritization is discussed under two different perspectives. The first is related to the manager's perception of the importance of the stakeholder. From this perspective, a form that hierarchizes the stakeholders by importance is the stakeholders' salience model, defined by Mitchell, Agle and Wood (1997, p.854) as the "the degree to which managers prioritize competing stakeholder claims". In the salience model, stakeholders are classified and hierarchized according to whether or not they have the attributes of power, legitimacy and urgency. The second perspective is associated to meeting stakeholders' interests.

\subsection{EMPIRICAL EVIDENCE OF STAKEHOLDER PRIORITIZATION}

There are still few empirical studies that deal with the topic of stakeholder prioritization. Most of the research that focus on the perception of the importance of the stakeholders by managers used the stakeholder salience model. Boesso and Kumar (2009) investigated the considerations that can be made by managers when choosing between expectations of mutually exclusive stakeholders. The authors also investigated engagement with stakeholders through disclosure of reports, conducting a comparative study between the USA and Italy. The research is based on the concept of salience, that is, they associate the prioritization to the managerial perception of three attributes: power, legitimacy and urgency. The authors verified that there are differences in the perception of attributes for each stakeholder, which could be explained by the nature of the company's relationship with the stakeholder. The results are not conclusive regarding the association between salience and stakeholder engagement. 
Parent and Deephouse (2007) studied the identification and prioritization of stakeholders based on the attributes of power, legitimacy and urgency. The authors conducted a case study, interviewing managers and found a positive relationship between the number of attributes and perceived saliency, emphasizing that the attribute power is the most important. Weber and Marley (2010) researched whether the stakeholder salience is related to the nationality of the company and the economic sector. The authors reviewed the sustainability reports released by the Fortune Global 100 companies. In the studied sample, the authors verified the relationship between the sector and the salience, confirming the hypothesis that the consumer stakeholder is more salient in sectors where there are sales and services directed to the final consumer, such as the retail, consumer products or financial services sectors. However, they do not confirm their second hypothesis, that industries that are more dependent on natural resources in their activities, such as energy, oil and gas, consider the environment as a more salient stakeholder than other industries. Neither did the authors find a relation between the nationality of the company and the prioritization of stakeholders.

Agle, Mitchell and Sonnenfeld (1999) empirically tested the salient model of stakeholders, emphasizing that the CEO's characteristics influence their perception regarding their attributes. In their study, the authors confirmed that attributes defined and perceived by the manager are related to the priority given to the stakeholder in cases of conflicting interests.

The research that investigated prioritization considering the level of the stakeholders' interests being met are scarcer. Michelon, Boesso and Kumar (2013) verified whether performance in seven areas of corporate social responsibility (CSR) - environment, community, corporate governance, diversity, labor relations, human rights and product quality - is associated with corporate performance and if the company prioritizes the most important CSR areas, allocating resources to these initiatives strategically. The results found by the authors pointed out that the allocation of resources to priority stakeholders is positively related to the company's financial performance. However, they did not find this relation for all seven areas.

Boaventura (2012) developed empirical research on stakeholder dominance, defined by the author as the ability of a particular stakeholder to obtain resources from a company to meet their demands in a preferential way in relation to other stakeholders. To empirically verify dominance, the author compared the meeting of demands of each group of stakeholders. In his empirical study, Boaventura (2012) found that the phenomenon of dominance occurs in Brazilian companies that were part of the sample, formed by publicly traded companies that answered the ISE questionnaire - Business Sustainability Index of BM\&FBovespa. The author also obtained a hierarchy of stakeholders according to the level of treatment, with employees and shareholders being the first group of dominance; second, community, society, customers and the environment; third, diversity; and fourth, suppliers.

Vazquez-Brust et al. (2010) studied the relationship between the perception of the stakeholders importance by the managers and the level stakeholders' interests fulfillment. The focus of the study by Vazquez-Brust et al. (2010) was the relation between the pressure by the stakeholders and the actions to protect the environment in Argentine companies. The authors verified that the treatment to the stakeholders, i.e., the response of the company to the pressure that the stakeholder exerts is related to the stakeholder's salience perceived by the managers. The authors verified that there are differences between the manager's perception of the importance of the stakeholder and the way in which the stakeholder is treated by the management.

In this sense, it is emphasized that the pressure or influence of the stakeholder can affect the strategies of the companies. Empirical studies, such as by Freitas and Hoffman (2012), highlight that managers consider the influence of stakeholders in the elaboration of the strategy. This influence can also affect the level of service that the stakeholder receives from the management. 
BBR

15,1

21

\subsection{RELATIONSHIP BETWEEN STAKEHOLDER PRIORITIZATION AND THE INDUSTRY}

Previous studies have also addressed industry and stakeholder relationships or the meeting of social issues. When studying 192 corporations, considering the perception of the managers, Holmes (1977) verified that each industry aimed its focus on different social issues. In the results, the author found, for example, that the oil, gas and mining industries focused on the environment; the transport and communication industries, focused on philanthropy and diversity actions; and the retail, finance and insurance and real estate industries, focused on the community, and in assisting philanthropic institutions. Despite not obtaining significant statistical results in all the tests, the author concludes that managers are moving towards a specialization of social interests, this specialization could be explained by the search to take advantage of the specific skills of the industry in social activities.

Carroll (1979) emphasized that social issues change according to industry, emphasizing that, for example, the banking sector suffers less environmental pressures than the manufacturing industry. Griffin and Mahon (1997) corroborate, emphasizing that different industries face different stakeholder configurations, with different degrees of activism in social issues. The authors then point to a limitation of the multi-industry studies, since the way CSP is measured may vary according to the industry under analysis. On this point, Waddock and Graves (1997) emphasize the importance of using industry as a control variable in the surveys that study the relationship between corporate social performance - CSP and corporate financial performance - CFP. Baird, Geylani and Roberts (2012) sought to analyze the CSP-CFP relationship with more robust methods and investigated the industry effect in this relation, finding significant results. The authors emphasize that each industry has unique characteristics that should be considered by managers when directing resources to stakeholders.

The relationship with the industry is also addressed in stakeholder salience studies. Weber and Marley (2010) investigated this relationship, proposing two hypotheses. The first asserts that industries that establish direct contact with the consumer, such as retail, financial and consumer goods, consider customers as stakeholders more salient than the other industries. The second argues that industries that are more dependent on natural resources in their activities, such as energy, oil and gas and utilities, consider the environment to be a more prominent stakeholder than other industries. In their empirical test, they confirmed the first hypothesis, but did not confirm the second one. And, in the end, they emphasized the importance of empirical research developments that seek to analyze the relationship of the industry with the aspects related to stakeholder management and corporate social responsibility - CSR.

\subsection{MEASUREMENT OF STAKEHOLDER INTERESTS FULFILLMENT}

In this research, stakeholder prioritization is operationally defined as the preferential treatment of the interests of one stakeholder in relation to another. The measurement of stakeholders interest fulfillment is related to the literature on corporate social performance - CSP, since the variables that normally compose CSP measure the performance in meeting the interests of stakeholders. According to Waddock (2004), CSP refers to practices and strategies for the relationship with stakeholders and the environment. Wood and Jones (1995) advocates the stakeholder theory as the basis for CSP, given its link with stakeholder expectations.

There are different ways of measuring CSP. Waddock and Graves (1997) cite the measures of perception, behavior and surveys; reputational indexes such as Fortune; case studies; 
and the content analysis of social and environmental documents and reports. Similarly, Orlitzky, Schmidt and Rynes (2003) cite the disclosure; reputational assessments; the social audits, processes and observable results; and management principles and values as ways of measuring CSP. The measurement of CSP through social disclosure consists of content analysis of annual reports and other disclosures of corporate information.

The use of social disclosure as a measure of social performance is based on the assumption that there is a relationship between disclosure and performance, which finds theoretical support in the voluntary disclosure theory. According to Guidry and Patten (2012), the literature on voluntary disclosure theory was initially based on the disclosure of financial information, and then extended to the dissemination of social and environmental information. Guidry and Patten (2012) add that the main studies supporting the application of voluntary disclosure theory in the environmental area are those by Verrecchia (1983), Dye (1985), and Lang and Lundholm (1993). In addition to the theoretical discussion on voluntary disclosure, empirical studies on the subject in Brazil can be found both for financial disclosure (KLANN; BEUREN, 2011) and for social disclosure (OLIVEIRA et al., 2006).

From the perspective of social disclosure, Vurro and Perrini (2011) use the voluntary disclosure theory to treat the relationship between CSR (corporate social responsibility) disclosure and CSR performance. One of the arguments for the relationship between CSR disclosure and CSR performance is that companies with a superior socio-environmental performance have greater incentive to disclose their actions and commitments, an assumption advocated by Verrecchia (1983) and corroborated by Lang and Lundholm (1993). Vurro and Perrini (2011) added that the greater the engagement with stakeholders, the greater the need for the organization to disclose its performance to them, positively impacting CSP.

Some studies that empirically analyzed the relationship between disclosure and performance found a positive relation, as those by Clarkson et al. (2008); Dawkins and Fraas (2011); Silva-Gao (2012); and Gallego-Álvarez (2012). Other studies found a negative relation, such as those by Sutantoputra, Lindorff and Johnson (2012) and Cho et al. (2012). It should be emphasized that the empirical investigation of the relationship between disclosure and performance is not consolidated (CLARKSON et al., 2008).

\section{RESEARCH HYPOTHESES}

Stakeholder prioritization, from the perspective of meeting interests, is still a field to be investigated in function of the theoretical discussion involving the normative and instrumental view of the theory, as well as the different variables that may interfere in the prioritization. Considering the large number of stakeholders that can affect an organization, it is relevant to group them to analyze their prioritization. A classification used in the literature is that of internal or external stakeholders, i.e., stakeholder prioritization may differ depending on their internal or external position to the organization.

According to Coff (1999), internal stakeholders have better information, critical skills for income generation and a high replacement cost. That is, internal stakeholders have greater bargaining power and capacity to appropriate income than other stakeholders. This greater power of internal stakeholders may cause them to exert more pressure on the organization to have their interests met.

For Hansen et al. (2011), although many studies focus on the impact of company actions on external stakeholders, such as customers, it is important to consider the impact of company actions on internal stakeholders, which are strictly related to the performance and success of the company. In her discussion, Brickson (2007) also groups the stakeholders as internal and external and argues that although customers and society (external) are very close to the organization, they may not be engaged so that managers fully meet their 
BBR

15,1

23

interests. In his empirical research, Boaventura (2012) shows that dominant stakeholders are the employee and shareholder, considered in the literature as internal stakeholders.

Therefore, internal stakeholders have greater proximity to management, which contributes to their interests being known by the company, and high bargaining power which can contribute to their better treatment. Therefore, we propose the hypothesis:

Hypothesis 1: Internal stakeholders have a higher level of attendance of their interests than external stakeholders.

Although there is a propensity for internal stakeholders to be better served, the industry in which the company is inserted may interfere with its prioritization. The influence of the industry can occur because the determinants of the bargaining power of internal stakeholders change according to the industry. These determinants, according to Coff (1999), are the unified capacity for action, access to key information, high replacement cost for the firm and its low cost to migrate to another company.

The employee is an internal stakeholder with high power. In terms of unified capacity for action, stronger unions can empower the employee (MARTINEZ; FIORITO; FERRIS, 2012), giving them joint action capacity. The other determinants of power also differ according to the industries. Løwendahl and Revang (1998) say that the higher the level of technology in the industry, in the communication and computing industries for example, the greater its internal complexity. This greater complexity makes the employees have more knowledge and skills and therefore more power. Another type of industry in which the employee can have greater power is that of services, which is highly dependent on human capital, presenting a high replacement cost (DALBEM; BASTIAN-PINTO; ANDRADE, 2014).

Thus, although the internal stakeholder is dominant, they can be prioritized in some types of industries and not prioritized in others. In order to analyze the influence of industry, we propose the hypothesis below:

Hypothesis 2: Internal stakeholders have a higher level of attendance of their interests in industries that have strong unions and are more reliant on technology and specific skills than in other industries.

\section{METHODOLOGY}

This research uses descriptive approach, employing documentary research when analyzing GRI reports for the study of stakeholder prioritization in Brazilian companies.

\subsection{SAMPLE SELECTION AND DATA COLLECTION}

The sample was constituted by companies that publish reports adopting the GRI structure. The data collection for this research was carried out in the GRI Database, selecting the criteria: (1) Year of publication: 2011; (2) Country: Brazil; (3) Report version: G3. The 2010 year-base reports were chosen because they appeared in greater quantity in the GRI Database in the data collection phase, in March 2013. After searching the GRI Database, only for-profit companies were selected and sustainability reports were collected from the GRI Database or from the companies' websites, when they were not available in the Database. At the end of the data collection, the final sample of this research was composed of 90 companies.

\subsubsection{GRI REPORTING STRUCTURE}

The GRI is an initiative created with the objective of increasing the practices of disclosing of social and environmental information. According to Waddock, Bodwell and Graves (2002), the GRI is the socio-environmental disclosure initiative considered the most important and widely accepted internationally. 
The GRI has developed a Framework for Sustainability Reporting (Sustainability Reporting Guidelines) which can be adopted by organizations of different sizes, sectors and localities (GLOBAL REPORTING INITIATIVE, 2006). The first version of the GRI framework was launched in 2000 and the second version in 2002. The third version (G3) was launched in 2006 and, in 2011, an update of the third version (G3.1). In 2013, version 4 (G4) of the GRI framework was launched.

The basic content of the sustainability report in the GRI structure is made up of three parts: (1) Strategy and Profile: Information that provides the general context for understanding organizational performance, including strategy, profile and governance; (2) Management Approach: Data whose objective is to explain the context in which the performance of the organization in a specific area must be interpreted; (3) Performance Indicators: Expose information about the organization's economic, environmental, and social performance that can be compared (GLOBAL REPORTING INITIATIVE, 2006).

We find in the literature of stakeholders, CSP, corporate social responsibility and environmental management studies that use GRI reports as data sources, such as the research by Moseñe et al. (2013); Mio (2010); Moroney, Windsor and Aw (2012); Sutantoputra, Lindorff and Johnson (2012); Prado-Lorenzo et al. (2009); and Jones et al. (2007).

\subsection{DEFINITION OF RESEARCH VARIABLES}

The variables of the research refer to the interests of stakeholders being met by the companies. In the structure of GRI indicators, we identified indicators that refer to meeting stakeholders' interests by organizations. Version 3 (G3) of the GRI Report Structure has a total of 79 indicators. Each indicator was associated with the interest of a stakeholder, with it being possible to associate 64 indicators to four stakeholders: employees (internal stakeholder), customers, the environment and society (external stakeholders). The four stakeholders are considered since they have more than five indicators associated to them. The indicators for each stakeholder are presented briefly in Table 1.

Table 1. Research variables

\begin{tabular}{|c|c|c|c|}
\hline Stakeholders & Indicator code & $\begin{array}{l}\text { Number of } \\
\text { indicators }\end{array}$ & $\begin{array}{l}\text { Description of the aspects covered in the } \\
\text { indicators }\end{array}$ \\
\hline Employees & $\begin{array}{c}\mathrm{EC} 3, \mathrm{EC} 5, \mathrm{EC} 7, \mathrm{LA} 1 \mathrm{a} \\
\text { LA14 }\end{array}$ & 17 & $\begin{array}{l}\text { Turnover, wages, benefits, health and safety at } \\
\text { work; training and education; diversity. }\end{array}$ \\
\hline Customers & PR1 to PR9 & 9 & $\begin{array}{l}\text { Consumer health and safety; Information } \\
\text { about the product; consumer satisfaction; } \\
\text { privacy breach and loss of customer data; } \\
\text { compliance of marketing and advertising } \\
\text { actions. }\end{array}$ \\
\hline Environment & EN1 to EN30 & 30 & $\begin{array}{l}\text { Aspects related to materials, energy, water, } \\
\text { biodiversity, emission, effluents and waste, } \\
\text { transportation, products and services, } \\
\text { and penalties for non-compliance with } \\
\text { environmental laws. }\end{array}$ \\
\hline Society & $\mathrm{SO} 1$ to $\mathrm{SO} 8$ & 8 & $\begin{array}{l}\text { Participation in the elaboration of public } \\
\text { policies; measures taken in response to cases } \\
\text { of corruption; lawsuits for unfair competition, } \\
\text { trustee and monopoly practices. }\end{array}$ \\
\hline
\end{tabular}

Source: Adapted from the Global Reporting Initiative (2006) 
BBR

15,1

25

In this research, we adopt the assumption that GRI indicators reflect the interests of stakeholders that are associated with them. This assumption is based on the CSP literature, since the information required by the GRI indicators corresponds to the variables used in the CSP literature to measure the interests of stakeholders, given the CSP being linked to stakeholders' expectations and interests (WOOD; JONES 1995; WADDOCK, 2004).

\subsection{MEASUREMENT OF STAKEHOLDER INTERESTS FULFILLMENT}

After defining the variables, we measured the level of stakeholders' interests being met. The measurement conducted from the GRI indicators considers the premise supported by the voluntary disclosure theory, that there is a relationship between disclosure and performance (VERRECCHIA, 1983; LANG; LUNDHOLM, 1993; VURRO; PERRINI, 2011). Considering this premise, the company that reports a GRI performance indicator related to stakeholder interest, is disclosing the organization's performance in meeting the stakeholder's interest.

Studies that used GRI articles as a data source carried out content analyzes of different forms. Some research carried out content analysis by developing scales of 4 to 7 points that classify the indicator between not being met and fully met (MIO, 2010; MORONEY; WINDSOR; AW, 2012; SUTANTOPUTRA; LINDORFF; JOHNSON, 2012). Other studies used a binary variable, indicating whether the indicator was met or not (CLARKSON et al., 2008; JONES et al., 2007; PRADO-LORENZO et al., 2009). Studies also classify indicators into three categories: whether it fully reports, partially reports or it does not report the indicator (MOSEÑE et al., 2013; MURGUÍA; BÖHLING, 2013).

In this research, three categories were defined: if the company fully reports, partially reports or it does not report the indicator. To verify that the GRI indicator has been reported, we analyzed the summaries disclosed by the companies that compose the GRI reporting framework. In the summary, the company indicates whether the indicator was fully or partially reported, or to justify why it did not report to a certain indicator. The indicators were analyzed one by one, assigning the number 1 for fully reporting, the value 0.5 for partially reporting, and the number 0 (zero) for not reporting.

After classifying each indicator, the frequency of indicators fully or partially reported in relation to the total indicators associated with each stakeholder. In case of the company informing in the report that the indicator does not apply, we excluded it from the count. The reporting frequency of the indicators was calculated for the four stakeholders individually, as well as for stakeholders grouped as internal and external. The measurement of the reporting frequency of the indicators, therefore, is the score of the level for meeting stakeholders' interests used for the statistical tests of this research.

\subsection{HYPOTHESES TEST}

To analyze the prioritization, it is necessary to compare the level of meeting stakeholders' interests. We performed this comparison using the non-parametric Mann-Whitney test. The Mann-Whitney test compares two groups of independent samples.

To test the first hypothesis, the level of meeting internal stakeholders' interests was compared with the level of meeting external stakeholders' interest of the total sample. For the second hypothesis test, the total sample was segmented into two types of industry: industries that have strong unions and are more dependent on technology and specific skills and industries with lower union strength and low dependence on technology and specific skills. After grouping the industries, the Mann-Whitney test was performed to compare the level of meeting internal and external stakeholders' interests within each group of industries. 


\section{RESULTS ANALYSIS}

The results will be presented according to the two specific objectives of the research: to identify the stakeholder prioritization of the companies; and to analyze the relationship between stakeholder prioritization and the industry variable.

The descriptive statistics of the variables related to meeting stakeholder interest, measured by the periodicity of reporting GRI indicators, are presented in Table 2.

Table 2. Descriptive statistics

\begin{tabular}{lccccccc}
\hline Stakeholders & Mean & Standard Deviation & Median & Sum & Minimum & Maximum & $\mathrm{N}$ \\
\hline Employee & 0.7808 & 0.22359 & 0.8235 & 70.27 & 0.12 & 1.00 & 90 \\
Customer & 0.6494 & 0.33214 & 0.7778 & 58.45 & 0.00 & 1.00 & 90 \\
Environment & 0.6889 & 0.31088 & 0.7500 & 62.00 & 0.00 & 1.00 & 90 \\
Society & 0.5985 & 0.31658 & 0.5592 & 53.87 & 0.03 & 1.00 & 90 \\
Internal Stakeholder & 0.7808 & 0.22359 & 0.8235 & 70.27 & 0.12 & 1.00 & 90 \\
External Stakeholder & 0.6248 & 0.29619 & 0.5886 & 56.24 & 0.09 & 1.00 & 90 \\
\hline
\end{tabular}

Source: Research data.

According to the statistics presented in Table 2, the employee stakeholder presents higher mean and median, and lower standard deviation. That is, the descriptive analysis already reveals a higher level of meeting interest of the employee stakeholder, the only internal stakeholder in the total sample analyzed. The environment stakeholder presents second highest average, followed by the buyer and by society. Grouping the external stakeholders, we observe that the mean and median are lower than the internal stakeholder. In the GRI structure, there is a greater number of indicators associated with external stakeholders, when the indicator did not apply to the type of organization, we withdrew the analysis indicator. Thus, in a descriptive way, a prioritization of the internal stakeholder is observed in comparison with the external stakeholders.

\subsection{STAKEHOLDER PRIORITIZATION}

The first specific objective of the research is to identify the stakeholder prioritization of the companies. For this purpose, the first research hypothesis was proposed: Internal stakeholders have a higher level of meeting their interests than external stakeholders. Table 3 presents the results of the Mann-Whitney test comparing the groups of internal and external stakeholders in the total sample.

Table 3. Stakeholder prioritization

\begin{tabular}{lcc}
\hline & Mean Rank & Sum of Ranks \\
\hline Internal Stakeholder & 104.31 & 9388.50 \\
External Stakeholder & 76.69 & 6902.50 \\
& Mann-Whitney U: 2807.000 & \\
& Asymp. Sig. (2-tailed): 0.000 & \\
\hline
\end{tabular}

Source: Research data.

The tests confirm Hypothesis 1 of the research, at the level of significance of $5 \%$. That is, there is a difference in the level of meeting the internal stakeholders' interests in relation to external stakeholders, because the mean for meeting interest of the internal stakeholder is greater than the mean for external stakeholders. In this research, the internal stakeholder analyzed is the employee, considered as one of the most powerful stakeholders and able to appropriate the value generated in the companies (COFF, 1999). This paper confirms 
BBR

15,1

27

the argument that employees have a high bargaining power in order for their interests to be met. Its proximity to management and importance to the company's performance also contributes for them to be considered as priority stakeholders, when compared to external stakeholders.

\subsection{ASSOCIATION BETWEEN STAKEHOLDER PRIORITIZATION AND INDUSTRY}

The second specific objective of the research is to analyze the relationship between stakeholder prioritization and the industry variable. For this purpose, we proposed the second research hypothesis: Internal stakeholders have a higher level of their interests being met in industries that have strong unions and are more reliant on technology and specific skills than in other industries.

By considering the employee as an internal stakeholder, the determinants of their bargaining power are the capacity for unified action, access to key information, the high cost of replacement for the firm and its low cost to migrate to another company (COFF, 1999). To analyze the power of the employee stakeholder in industries, it is necessary to analyze the determinants of their power.

In this research, the sectorial segmentation proposed by the GRI was used to analyze the power of the employee in each industry. Table 4 presents the evaluation of the power of the employee in each industry according to the determinants, with it being classified as high power or low power.

Table 4. Companies by industry

\begin{tabular}{|c|c|c|c|c|c|}
\hline Industry & $\mathrm{N}$ & $\begin{array}{l}\text { Unified } \\
\text { Action }\end{array}$ & $\begin{array}{c}\text { Key } \\
\text { Information }\end{array}$ & Replacement cost & $\begin{array}{l}\text { Migration to ano- } \\
\text { ther company }\end{array}$ \\
\hline Agriculture & 3 & & & Low & Low \\
\hline Food \& Beverage & 2 & & & Low & Low \\
\hline Automotive & 1 & & High & High & \\
\hline Aviation & 1 & & High & High & \\
\hline Durable consumer goods & 1 & & & Low & Low \\
\hline Computers & 1 & & High & High & \\
\hline Construction & 6 & & & Low & Low \\
\hline Water distribution & 1 & & High & High & \\
\hline Energy: Distribution & 13 & & High & High & \\
\hline Energy: Generation & 13 & & High & High & \\
\hline Finance & 9 & High & High & High & \\
\hline Chemical Industry & 2 & & High & High & \\
\hline Construction Materials & 1 & & & Low & Low \\
\hline Mechanical metal & 2 & High & & & \\
\hline Media & 2 & & High & High & \\
\hline Mining & 4 & & High & High & \\
\hline Paper And Pulp & 6 & & High & High & \\
\hline Household and personal products & 2 & & & Low & Low \\
\hline Business services & 2 & High & High & High & \\
\hline Health services & 2 & & High & High & \\
\hline Technology & 3 & & High & High & \\
\hline Telecommunications & 1 & & High & High & \\
\hline Retail & 1 & & & Low & Low \\
\hline Total & 79 & & & & \\
\hline
\end{tabular}


Table 4 shows the evaluation of the determinants of the power of the employees in the industries. The capacity for unified action is related to the work of the unions, since stronger unions can grant greater power to the employees (MARTINEZ; FIORITO; FERRIS, 2012). Therefore, more active trade unions in Brazil, such as those of bankers, traders and metallurgists, can give employees in the financial, trade, and metalworking service industries greater unified action capability.

Access to key information and high replacement cost are characteristics of more specialized employees. More dynamic, high-tech and communication industries have more skilled and critical-skilled employees (LØWENDAHL; REVANG, 1998). Therefore, more dynamic and high technology industries (automotive, aviation, computers, media, technology and telecommunications) may have more specialized employees than in less dynamic industries (food and beverage, consumer goods, household goods and retail).

Industries that present more specialized activities also demand professionals with critical skills, which have a high replacement cost and greater difficulty in migrating to other companies, such as in the energy, water, chemical, mining and paper and pulp industries. Service companies are also dependent on human capital, which have a high replacement cost (DALBEM; BASTIAN-PINTO; ANDRADE, 2014), as in the financial, trade and health services industries. On the other hand, professionals in agriculture have low schooling and perform a less sophisticated and dynamic activity (HOFFMAN; NEY, 2004). In the construction industry there are also low-skilled workers and a trend of high mobility of labor (ARAUJO JUNIOR; NOGUEIRA; SHIKIDA, 2012). In this sense, in the agriculture and construction industries the employees have low power.

In Table 4, two GRI sectoral segmentations were not classified: Others (with 7 companies) and Conglomerates (with 4 companies), due to the difficulty of jointly evaluating, characteristics of the companies in these segmentations. Therefore, the total sample for the analysis of the industry influence is composed of 79 companies.

To test the influence of the industry on prioritization, we grouped the industries with high-level employees in the first group and the industries with low-level employees in the second group. Group 1 - industries with high-power employees - is composed of 63 companies, and Group 2 - industries with low-power employees - is composed of 16 companies. We used the Mann-Whitney test to evaluate whether the level of meeting internal stakeholders' (employees) interests is higher in the companies of the first group, and if it is lower or neutral in the companies of the second group. The test results are presented in Table 5.

Table 5. Stakeholder Prioritization in industries

\begin{tabular}{lccc}
\hline & & Mean Rank & Sum of Ranks \\
\hline & Internal Stakeholder & 73.09 & 4604.50 \\
Group 1: Industries with & External Stakeholder & 53.91 & 3396.50 \\
high-powered employees & & Mann-Whitney U: 1380.50 & \\
& & Asymp. Sig. (2-tailed): 0.003 & Sum of Ranks \\
& & Mean Rank & 308.00 \\
Group 2: Industries with & Internal Stakeholder & 19.25 & 220.00 \\
low-powered employees & External Stakeholder & 13.75 & \\
& & Mann-Whitney U: 84.000 & \\
& & Asymp. Sig. (2-tailed): 0.096 & \\
\hline
\end{tabular}

Source: Research data. 
BBR

15,1

29

The results of Table 5 confirm the hypothesis that internal stakeholders are better served in industries with strong unions, greater dependence on technology and specific skills, that is, they have more powerful employees. Internal stakeholder service, compared to external stakeholders, is higher in Group 1 at a significance level of 5\%. In addition, there is no statistically significant difference (at the 5\% level) between meeting internal and external stakeholders in Group 2. That is, the results reveal the prioritization of the employee in Group 1 and the non-prioritization of the employee in Group 2.

Many studies highlight the importance of the employee as an internal stakeholder. This study also confirms the importance of the employee stakeholder, finding a high level of meeting these stakeholders' interest in the analyzed sample. We can also observe the influence of the industry on the prioritization of this stakeholder. Although the subsamples have unbalanced sizes, we confirmed in the analyzed sample a greater prioritization of the internal stakeholders in the industries in which they have greater power.

\section{CONCLUSION}

This objective of this research is to analyze stakeholder prioritization in Brazilian companies and its relation with industry (economic sector). Stakeholder prioritization was operationally defined as the preferential treatment of the interests of one stakeholder over another. Meeting the interests of stakeholders was measured in the annual reports disclosed by Brazilian companies with the structure of the GRI.

This study contributes to the analysis of the industry factor in stakeholder prioritization and compares the level of interest fulfillment of internal and external stakeholders to the organization. We confirmed the hypothesis that the internal stakeholder has a higher level of attendance of their interests and that this attendance is affected by characteristics of the industries. The results pointed out that in industries that have strong unions, and with greater dependence on technology and specific skills, the internal stakeholder employee has a higher level of attendance, which does not occur in other types of industry.

Managers deal with conflicting interests and scarce resources, so the factors that determine prioritization are important for management. The internal stakeholders of the company exert more pressure, due to their proximity to the management and influence on the performance of the company. Managers must meet them, however, avoiding that a super allocation for the employees compromises the allocation of resources to other stakeholders of the organization. In some industries, external stakeholders can exert large influence on the organization's competitiveness and a high potential for cooperation, which are not used by the organization because their interests are neglected by management because of their low commitment.

With this study, recommendations emerge of academic and practical nature. The recommendations of an academic nature are the study of possible trade-offs in stakeholder prioritization in Brazilian companies. Whereas the efficient allocation of resources is a challenge for the business administration, studies on the prioritization criteria for stakeholder treatment are relevant and have potential for future research. As recommendations of a practical nature, we reinforce the premise that managers should consider the contributions and influence of stakeholders in the company's competitiveness within the industry that they operate in, to establish criteria for meeting stakeholder interests according to their contribution to the company's competitiveness in the industry.

\section{REFERENCES}

AGLE, B. R.; MITCHELL, R. K.; SONNENFELD, J. A. Who matters to CEOs? An investigation of stakeholder attributes and salience, corporate performance and CEO values. Academy of Management Journal, v.42, n.5, p.507-525, 1999. 
ARAUJO JUNIOR, A. F.; NOGUEIRA, D. G.; SHIKIDA, C. D. Análise da eficiência das firmas de construção civil nacionais. BBR-Brazilian Business Review, v. 9, n. 3, p. 47-71, 2012.

BAIRD, P. L.; GEYLANI, P. C.; ROBERTS, J. A. Corporate Social and Financial Performance Re-Examined: Industry Effects in a Linear Mixed Model Analysis. Journal of Business Ethics, v. 109, n. 3, p. 367-388, 2012.

BOAVENTURA, J. M. G. Dominância de Stakeholders em Empresas Brasileiras: Contribuições à Teoria dos Stakeholders. Tese (Livre Docência), Universidade de São Paulo, São Paulo, 2012, 116 p.

BOAVENTURA, J. M. G.; CARDOSO, F. R.; SILVA, E. S.; SILVA, R. S. Teoria dos stakeholders e teoria da firma: estudo sobre a hierarquização da função-objetivo em empresas brasileiras. Revista Brasileira de Gestão de Negócios, v. 11, n. 32, p. 289-307, 2009.

BOESSO, G.; KUMAR, K. Stakeholder prioritization and reporting: Evidence from Italy and the US. Accounting Forum, v.33, n.2, p.162-175, 2009.

BRICKSON, S. L. Organizational identity orientation: The genesis of the role of the firm and distinct forms of social value. Academy of Management Review, v. 32, n. 3, p. 864-888, 2007.

CARROLL, A. B. A three-dimensional conceptual model of corporate performance. Academy of Management Review, v.4, n.4, p.497-505, 1979.

CHO, C. H.; GUIDRY, R. P.; HAGEMAN, A. M.; PATTEN, D. M. Do actions speak louder than words? An empirical investigation of corporate environmental reputation. Accounting, Organizations and Society, v.37, n.1, p.14-25, 2012.

CLARKSON, P. M.; LI, Y.; RICHARDSON, G. D.; VASVARI, F. P. Revisiting the relation between environmental performance and environmental disclosure: An empirical analysis. Accounting, Organizations and Society, v.33, n.4-5, p.303-327, 2008.

COFF, R. W. When competitive advantage doesn't lead to performance: The resource-based view and stakeholder bargaining power. Organization Science, v. 10, n. 2, p. 119-133, 1999.

DALBEM, M. C.; BASTIAN-PINTO, C. L.; ANDRADE, A. M. O valor financeiro do capital humano e o desafio de retê-lo nas empresas. BBR-Brazilian Business Review, v. 11, n. 1, p. 51-72, 2014.

DAWKINS, C.; FRAAS, J. W. Coming Clean: The Impact of Environmental Performance and Visibility on Corporate Climate Change Disclosure. Journal of Business Ethics, v.100, n.2, p.303-322, 2011.

DYE, R. A. Disclosure of Nonproprietary Information. Journal of Accounting Research, v.23, n.1, p.123$145,1985$.

FREEMAN, R. E. Strategic management: a stakeholder approach. Boston: Pitman, 1984.

FREITAS, C. A.; HOFFMANN, V. E. A Percepção das estratégias de influências dos stakeholders e sua relação com a estratégia genérica: estudo de caso em pequenas empresas comerciais do litoral norte Catarinense. BBR - Brazilian Business Review, v. 9, n. 2, p. 1-25, 2012.

GALLEGO-ÁLVAREZ, I. Indicators for Sustainable Development: Relationship between Indicators Related to Climate Change and Explanatory Factors. Sustainable Development, v.20, n.4, p.276-292, 2012.

GLOBAL REPORTING INITIATIVE. Diretrizes para Relatório de Sustentabilidade - G3. GRI, 2006. Disponível em: < https://www.globalreporting.org/resourcelibrary/Portuguese-G3-Reporting-Guidelines. pdf $>$. Acesso em: 15/08/2012.

GRIFFIN, J. J.; MAHON, J. F. The corporate social performance and corporate financial performance debate: Twenty-five years of incomparable research. Business \& Society, v. 36, n. 1, p. 5-31, 1997.

GUIDRY, R. P.; PATTEN, D. M. Voluntary disclosure theory and financial control variables: An assessment of recent environmental disclosure research. Accounting Forum, v.36, n.2, p.81-90, 2012.

HANSEN, S. D.; DUNFORD, B. B.; BOSS, A. D.; BOSS, R. W.; ANGERMEIER, I. Corporate social responsibility and the benefits of employee trust: A cross-disciplinary perspective. Journal of Business Ethics, v. 102, n. 1, p. 29-45, 2011.

HOFFMANN, R.; NEY, M. G. Desigualdade, escolaridade e rendimentos na agricultura, indústria e serviços, de 1992 a 2002. Economia e Sociedade, v.13, n. 2(23), p.51-79, 2004.

HOLMES, S. L. Corporate Social Performance: Past and Present Areas of Commitment. Academy of Management Journal, v. 20, n. 3, p. 433-438, 1977.

JONES, S.; FROST, G.; LOFTUS, J.; LAAN, S. V. D. An Empirical Examination of the Market Returns and Financial Performance of Entities Engaged in Sustainability Reporting. Australian Accounting Review, v. 17, n. 1, p. 78-87, 2007. 
BBR

15,1

KLANN, R. C.; BEUREN, I. M. Características de empresas que influenciam o seu disclosure voluntário de indicadores de desempenho. BBR - Brazilian Business Review, v. 8, n. 2, p. 96-118, 2011.

LANG, M.; LUNDHOLM, R. Cross-Sectional Determinants of Analyst Ratings of Corporate Disclosures. Journal of Accounting Research, v.31, n.2, p.246-271, 1993.

LØWENDAHL, B.; REVANG, Ø. Challenges to existing strategy theory in a postindustrial society. Strategic Management Journal, v. 19, n. 8, p. 755-773, 1998.

MARTINEZ, A. D.; FIORITO, J.; FERRIS, G. R. Relationship between union strength and supervisor-subordinate power relations. Journal of Managerial Psychology, v. 27, n. 2, p. 132-142, 2012.

MICHELON, G.; BOESSO, G.; KUMAR, K. Examining the Link between Strategic Corporate Social Responsibility and Company Performance: An Analysis of the Best Corporate Citizens. Corporate Social Responsibility and Environmental Management, v.20, n.2, p.81-94, 2013.

MIO, C. Corporate Social Reporting in Italian Multi-utility Companies: An Empirical Analysis. Corporate Social Responsibility and Environmental Management, v. 17, n. 5, p. 247-271, 2010.

MITCHELL, R. K.; AGLE, B. R.; WOOD, D. J. Toward a theory of stakeholder identification and salience: defining the principle of who and what really counts. Academy of Management Review, v.22, n.4, p.853$886,1997$.

MORONEY, R.; WINDSOR, C. A.; AW, Y. T. Evidence of assurance enhancing the quality of voluntary environmental disclosures: an empirical analysis. Accounting \& Finance, v. 52, n. 3, p. 903-939, 2012.

MOSEÑE, J. A.; BURRITT, R. L.; SANAGUSTÍN, M. V.; MONEVA, J. M.; TINGEY-HOLYOAK, J. Environmental reporting in the Spanish wind energy sector: an institutional view. Journal of Cleaner Production, v. 40, p. 199-211, 2013.

MURGUÍA, D. I.; BÖHLING, K. Sustainability reporting on large-scale mining conflicts: the case of Bajo de la Alumbrera, Argentina. Journal of Cleaner Production, v. 41, p. 202-209, 2013.

OLIVEIRA, M. C.; OLIVEIRA, B. C.; DAHER, W. M.; RIBEIRO, M. S. Análise Segundo o Modelo de Hopkins das Ações de Responsabilidade Social Empresarial Evidenciadas nas Demonstrações Contábeis e Balanços Sociais - O Caso das Distribuidoras de Energia do Grupo Brasileiro Neoenergia. BBR - Brazilian Business Review, v. 3, n. 1, p. 32-45, 2006.

ORLITZKY, M.; SCHMIDIT, F. L.; RYNES, S. L. Corporate social and financial performance: a meta-analysis. Organization Studies, v.24, n.3, p.403-441, 2003.

PARENT, M. M.; DEEPHOUSE, D. L. A Case Study of Stakeholder Identification and Prioritization by Managers. Journal of Business Ethics, v.75, n.1, p.1-23, 2007.

PHILLIPS, R. A. Stakeholder theory and organizational ethics. San Francisco: Berrett-Koehler Publishers, 2003.

PHILliPS, R. A.; FREEMAN, R. E.; WICKS, A. C. What Stakeholder Theory Is Not. Business Ethics Quarterly, v.13, n.4, p.479-502, 2003.

PRADO-LORENZO, J. M.; RODRÍGUEZ-DOMÍNGUEZ, L.; GALLEGO-ÁLVAREZ, I.; GARCÍA-SÁNCHEZ, I. M. Factors influencing the disclosure of greenhouse gas emissions in companies world-wide. Management Decision, v. 47, n. 7, p. 1133-1157, 2009.

SILVA-GAO, L. The Disclosure of Environmental Capital Expenditures: Evidence from the Electric Utility Sector in the USA. Corporate Social Responsibility and Environmental Management, v.19, n.4, p.240-252, 2012.

SUTANTOPUTRA, A. W.; LINDORFF, M.; JOHNSON, E. P. The relationship between environmental performance and environmental disclosure. Australasian Journal of Environmental Management, v.19, n.1, p.51-65, 2012.

VAZQUEZ-BRUST, D. A.; LISTON-HEYES, C.; PLAZA-ÚBEDA, J. A.; BURGOS-JIMÉNEZ, J. Stakeholders Pressures and Strategic Prioritisation: An Empirical Analysis of Environmental Responses in Argentinean Firms. Journal of Business Ethics, v.91, n.S2, p.171-192, 2010.

VERRECCHIA, R. E. Discretionary Disclosure. Journal of Accounting and Economics, v.5, p.179-194, 1983.

VURRO, C.; PERRINI, F. Making the most of corporate social responsibility reporting: disclosure structure and its impact on performance. Corporate Governance, v.11, n.4, p.459-474, 2011.

WADDOCK, S. A. Parallel universes: Companies, academics, and the progress of corporate citizenship. Business and Society Review, v.109, n.1, p.5-42, 2004.

WADDOCK, S. A.; BODWELL, C.; GRAVES, S. B. Responsibility: The new business imperative. Academy of Management Executive, v. 16, n. 2, p. 132-148, 2002.

WADDOCK, S. A.; GRAVES, S. B. The Corporate Social Performance - Financial Performance Link. Strategic Management Journal, v.18, n.4, p.303-319, 1997. 
WEBER, J.; MARLEY, K. A. In Search of Stakeholder Salience: Exploring Corporate Social and Sustainability Reports. Business \& Society, v.51, n.4, p.626-649, 2010.

WOOD, D. J.; JONES, R. E. Stakeholder Mismatching: A Theoretical Problem In Empirical Research On 229-267, 1995. 